\title{
The rationale for treating allergic asthma
}

\section{with anti-lgE}

\section{E. Hamelmann}

ABSTRACT: An estimated two-thirds of asthma is allergic and $>\mathbf{5 0} \%$ of severe asthma has an allergic component. An increased immunoglobulin (Ig)E production in response to environmental allergens (atopy) is the strongest detectable predisposing factor for the development of asthma, particularly when sensitisation occurs early in life.

IgE binds to high-affinity receptors (FcERI) on effector cells, such as mast cells and basophils. Allergen binds to $\mathrm{IgE}$ and initiates an inflammatory cascade resulting in release of proinflammatory mediators that contribute to the acute and chronic symptoms of allergic airway diseases. By reducing serum IgE levels and Fc\&RI receptor expression on key cells in the inflammatory cascade, omalizumab blocks the release of inflammatory mediators from mast cells and reduces the infiltration of inflammatory cells, notably eosinophils, into the airway. In patients with allergic asthma, omalizumab inhibits both the early and late asthmatic response and several other markers of inflammation, including the requirement for inhaled or oral corticosteroids.

The anti-inflammatory effects of omalizumab provide proof-of-concept of the key role played by immunoglobulin $\mathrm{E}$ in allergic respiratory disease. Omalizumab represents a novel approach to the treatment of asthma, inhibiting the inflammatory cascade before it starts.

KEYWORDS: Airway inflammation, allergic asthma, anti-immunoglobulin E, immune modulation, monoclonal antibody, omalizumab

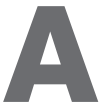
pproximately two-thirds of asthma is allergic and $>50 \%$ of patients with severe asthma have allergic asthma [1-3]. Allergic (immunoglobulin (Ig)E-mediated) asthma is characterised by the presence of $\operatorname{IgE}$ antibodies against one or more common environmental allergens, such as house dust mite, animal danders and moulds [4]. Omalizumab represents a novel approach to the treatment of severe persistent allergic asthma. It is a humanised monoclonal antiIgE antibody, the first therapeutic agent which has been demonstrated to bind free IgE and inhibit mast cell degranulation [5].

\section{ATOPY}

Atopy is the production of increased levels of $\operatorname{IgE}$ in response to common environmental allergens and is the strongest detectable predisposing factor for the development of asthma [4]. In the German Multicenter Allergy Study (MAS)-90, 499 newborns with risk factors for atopy and 815 newborns with no risk factors were followed up at specified intervals until they reached 13 yrs of age, using structured parental interviews (with special interest paid to asthmatic and atopic symptoms), blood sampling to determine specific IgE antibodies to food and inhalant allergens, and a bronchial histamine challenge performed at
7 yrs of age [6]. MAS-90 demonstrated that atopy and a positive family history for asthma/atopy was associated with the prevalence of asthma at age $7 \mathrm{yrs}$ and that the prevalence of asthma was greatest in children with persistent sensitisation and a positive family history (fig. 1) [6].

The frequency of wheezing episodes from birth up to the age of 5 yrs was equivalent for children with atopic and nonatopic wheeze. Early onset of wheeze and repeated episodes of wheeze before the age of 3 yrs were not significantly different between groups. At school age (5-7 yrs), the severity of asthma symptoms was higher among the atopic group, as assessed by the frequency of wheezing episodes in the previous year [7]. After 5 yrs of age, the course of wheezing differed markedly between groups. In children with nonatopic wheeze, the prevalence of symptoms diminished substantially in subsequent years, whereas the prevalence of symptoms first increased and then remained stable over the following years among the children with atopic wheeze. At age 13 yrs, $90 \%$ of children with nonatopic wheeze had a remission of symptoms, compared with $\sim 56 \%$ children with atopic wheeze ( $p=0.0002$; fig. 2 ). Early sensitisation to perennial allergens significantly affected lung
CORRESPONDENCE

E. Hamelmann

Charité Universitaetsmedizin Berlin

Dept of Paediatric Pneumology and

Immunology

Augustenburger Platz 1

13353 Berlin

Germany

Fax: 4930450559951

E-mail: eckard.hamelmann@

charite.de

STATEMENT OF INTEREST

This issue of the European

Respiratory Review contains proceedings of a satellite symposium held at the 16th ERS Annual Congress, 2006, which was sponsored by Novartis Pharma AG. The authors were assisted in the preparation of the text by professional medical writers at ACUMED $_{\mathbb{B}}$; this support was funded by Novartis Pharma AG. 


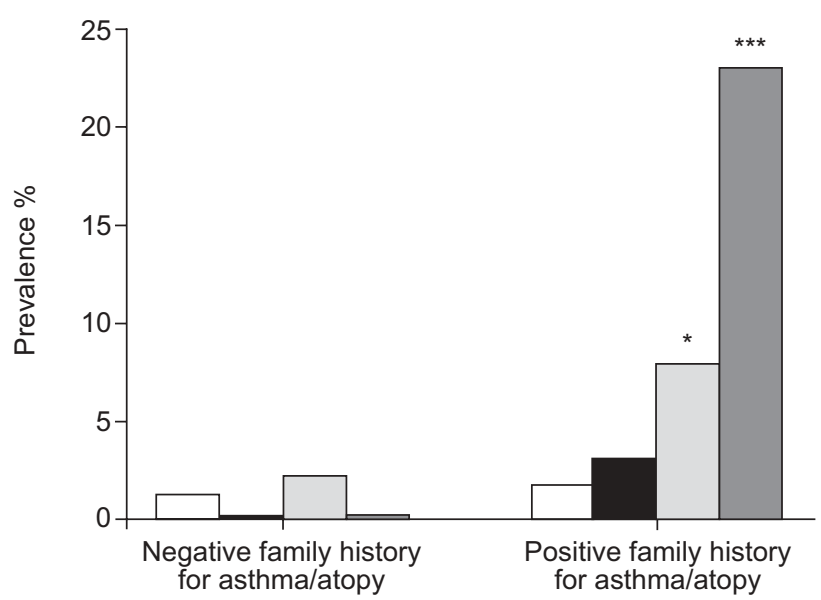

FIGURE 1. Prevalence of asthma at age $7 \mathrm{yrs}$, stratified for sensitisation pattern and family history. $\square$ : no sensitisation ( $n=183$ and $n=158$ for the negative and positive groups, respectively); $\mathbf{~ : ~ t r a n s i e n t ~ s e n s i t i s a t i o n ~}(n=47$ and $n=33$,

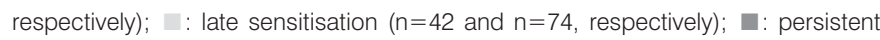
sensitisation ( $n=29$ and $n=70$, respectively). *: $p<0.05 ; * * *: p<0.001$ in comparison to no sensitisation/negative family history (Chi-squared test). Data taken from [6].

function at school age; later sensitisation to these allergens had a less pronounced effect.

\section{ROLE OF IgE IN ALLERGIC ASTHMA}

Binding of $\operatorname{IgE}$ to high-affinity receptors (FceRI) on effector cells, such as mast cells and basophils, and subsequent exposure to allergen initiates an inflammatory cascade resulting in release of pro-inflammatory mediators, which contribute to the acute and chronic symptoms of allergic airway diseases [8].

The $\operatorname{IgE}$ molecule is comprised of fragments known as the antigen-binding fragment (Fab) and the crystallisable fragment (Fc; fig. 3). The Fab region binds to specific components (or

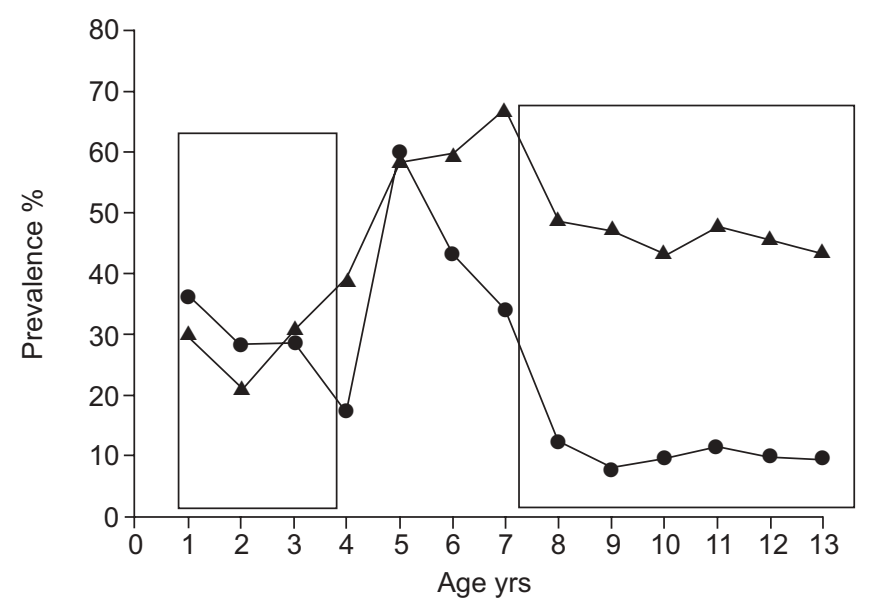

FIGURE 2. Prevalence of current wheeze from birth to age $13 \mathrm{yrs}$ in children with any wheezing episode at school age (5-7 yrs), stratified for atopy ( nonatopic; $\mathbf{\Lambda}$ : atopic) at school age. The boxes demonstrate that atopy is a risk factor for persistent/chronic asthma at school age, whereas it does not discriminate early wheezers in infancy. Reproduced, with modifications, from [7] with permission from the publisher. epitopes) of the allergen, whereas the Fc region binds to FceRI present on mast cells and circulating basophils. FceRI consist of four polypeptide chains, $\alpha \beta \gamma_{2}$. The $\alpha$ chain binds to five amino acids (330-335) of the C 83 domain of the Fc segment of IgE in order to orientate the $\operatorname{IgE}$ molecule such that it lies with the allergen-binding site facing outwards (fig. 4) [8].

The binding of allergen to two or more adjacent $\alpha$ chains results in receptor clustering and, through interactions involving the $\alpha$ and $\beta$ chains, sets into motion intracellular biochemical events that trigger mast cell activation [8]. This activation releases a variety of pre-formed and newly generated pro-inflammatory mediators and cytokines, including histamine, interleukins (ILs), leukotrienes and prostaglandins (type I hypersensitivity reaction). The release of IL-4, IL-13 (increasing IgE synthesis) and IL-5 (increasing eosinophil accumulation) contributes to the chronic inflammatory response (fig. 5). Eosinophilia is a well-recognised feature of inflammation in asthma and it reflects asthma severity and the risk of exacerbations $[9,10]$.

IgE upregulates FceRI on mast cells and basophils [11]. This upregulation of FceRI expression in the presence of higher concentrations of serum $\mathrm{IgE}$ results in mast cell stimulation and mediator release at lower concentrations of allergen, and/ or in the release of increased amounts of mediators and cytokines for a given level of stimulus [12]. IgE also binds FceRI on dendritic cells and enhances allergen uptake and presentation to T-cells [13], leading to increased T-cell proliferation and eosinophil differentiation and activation.

It is well established that the risk of developing asthma increases with increasing levels of serum $\operatorname{IgE}$ (fig. 6) [14]. However, asthma severity is poorly associated with total $\mathrm{IgE}$ levels [15]. The association between specific IgE and asthma severity is currently under investigation. FceRI are upregulated on eosinophils, mast cells, macrophages and dendritic cells in patients with rhinitis [16] and allergic asthma [17]. In addition, a significant correlation has been observed between serum IgE levels and FceRI expression on precursor dendritic cells from subjects with allergic asthma [18]. A possible relationship between FceRI expression and fatal asthma has also been reported [19]. This study examined post mortem human lung tissue and found that cases of fatal asthma were associated with higher levels of FccRI-positive cells within the lamina propria, compared with subjects who died of other causes or with biopsy tissue from patients with mild asthma (fig. 7).

\section{TARGETING IgE}

Omalizumab (Xolair ${ }^{\circledR}$ ) is a recombinant, humanised monoclonal antibody and it is the first treatment to target $\operatorname{IgE}$. Omalizumab reduces free IgE by $\sim 95 \%$ by binding to the C 83 region on free $\operatorname{IgE}$, thereby blocking the binding of $\operatorname{IgE}$ to its specific high-affinity receptor. IgE enhances the expression of FceRI on effector cells [11] and, in conditions of reduced levels of plasma $\operatorname{IgE}$, the reverse is also true. In a series of in vitro studies [5, 20], the effect of anti-IgE treatment on the expression of FceRI on basophils in subjects with perennial allergic rhinitis and with positive skin test to dust mite was examined. Basophil receptor density measurements were taken prior to treatment and 3 months after treatment initiation. With omalizumab treatment, total FceRI density was decreased 


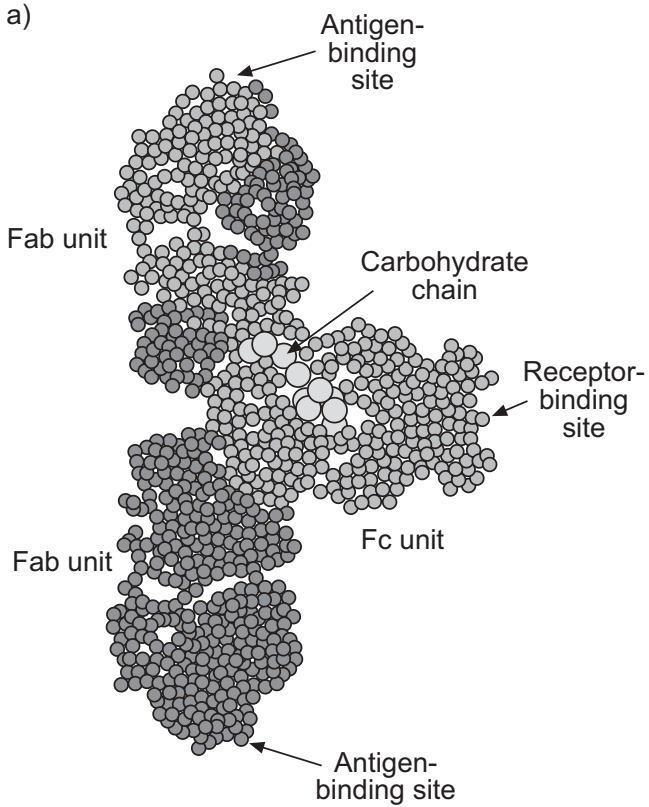

b)

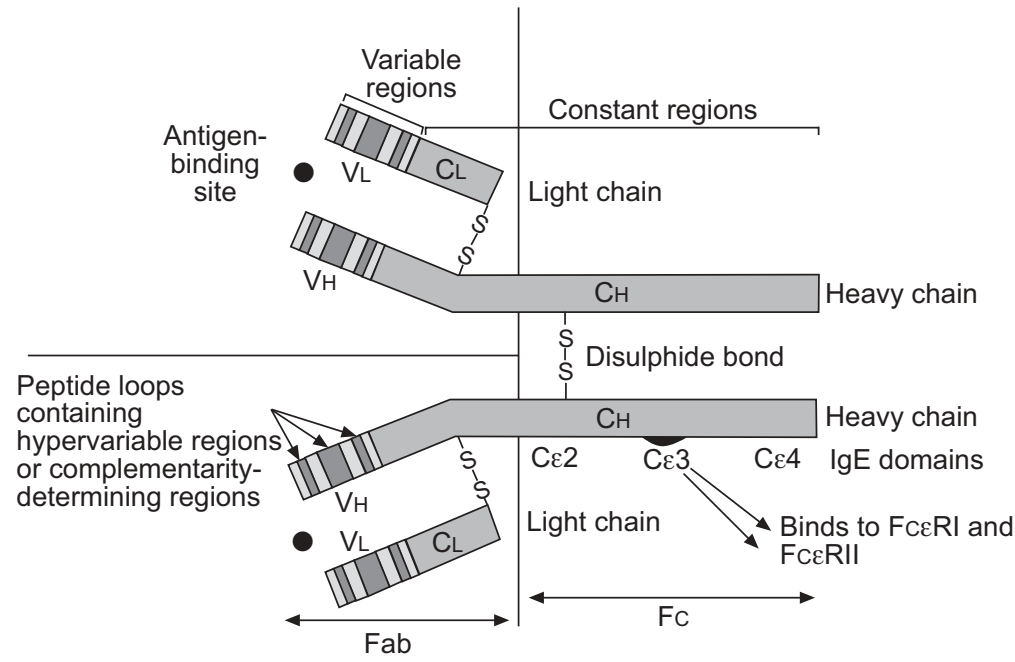

FIGURE 3. a) Molecular structure and b) schematic diagram of immunoglobulin (Ig)E. The variable domain (V) binds antigen. The constant region (C) domains

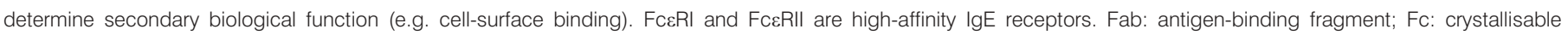
fragment; $\mathrm{VH}$ : heavy-chain variable domain; VL: light-chain variable domain; $\mathrm{CH}$ : heavy-chain constant domain; $\mathrm{CL}$ : light-chain variable domain.

by $\sim 97 \%$ ( $p=0.0022$; fig. 8) [5]. Reflecting the reduction in receptor density, the responsiveness of the basophils to challenge with dust mite antigen (Dermatophagoides farinae) was decreased by $\sim 90 \% \quad(p=0.0022)$ [5]. During the period following discontinuation of omalizumab treatment, basophil FceRI were upregulated, concurrent with a gradual rise of serum-free IgE levels to $16 \%$ of pre-treatment levels over an 8 week period [20]. However, a more rapid rise in antigentriggered histamine release responses by the cells implies a reduction of the threshold for basophil activation. Thus, the effects of omalizumab treatment on mast cells and basophils are achieved through a combination of reduced free IgE levels and $\operatorname{IgE}$ receptor downregulation, leading to the inhibition of

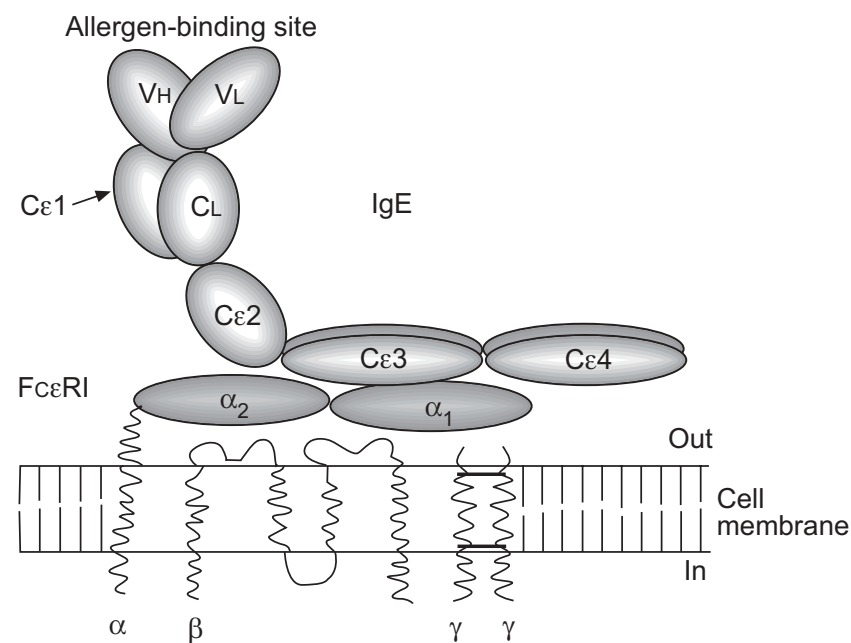

FIGURE 4. Binding of immunoglobulin (Ig)E to the high-affinity receptor (FcERI). Reproduced from [8] with permission from the publisher.
IgE-mediated pro-inflammatory mediator release. These dual effects of omalizumab are important, since without the FceRI downregulation almost complete removal of free IgE would be necessary to elicit functional consequences on mast cells and basophils $[5,20]$.

Omalizumab significantly reduces submucosal IgE-positive and FceRI-positive cells in patients with allergic asthma. The effect of omalizumab on the number of cells expressing IgE or FceRI was assessed in a placebo-controlled study of 45 patients with corticosteroid-naïve, mild-to-moderate asthma [21].

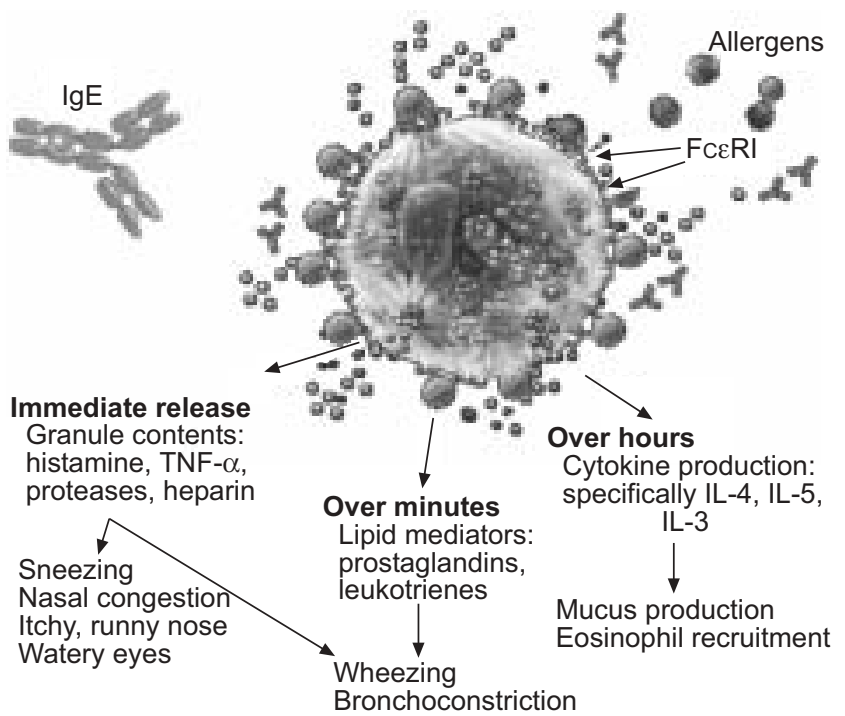

FIGURE 5. Immunoglobulin (Ig)E-dependent release of inflammatory mediators. IL: interleukin; FcERI: high-affinity IgE receptor; TNF: tumour necrosis factor. 


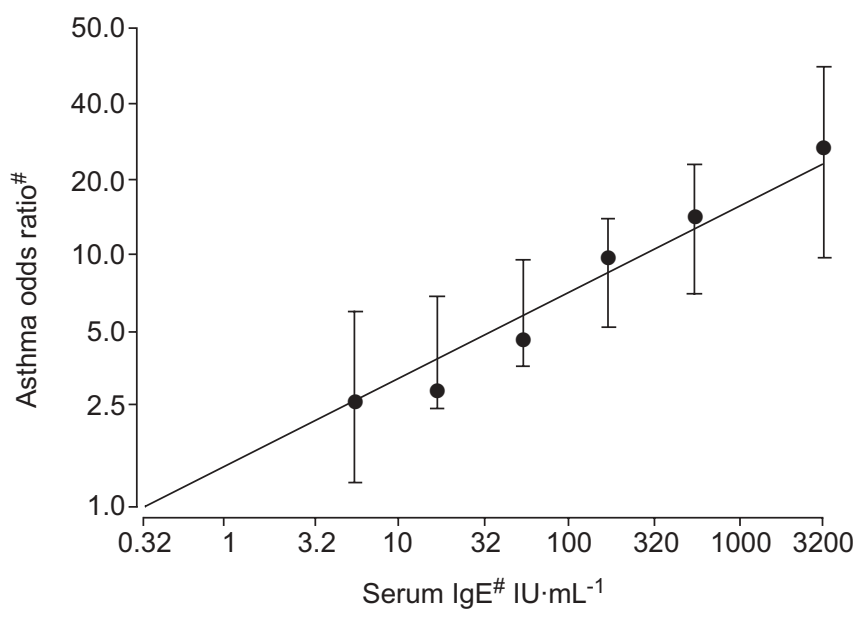

FIGURE 6. The likelihood of having asthma increases with increasing serum immunoglobulin $(\mathrm{lg}) \mathrm{E}(\mathrm{n}=2,657)$. The error bars represent the 95\% confidence intervals. \#: logarithmic scale. Reproduced from [14] with permission from the publisher.

Treatment with omalizumab for 16 weeks significantly reduced IgE-positive cells in the bronchial submucosa compared with baseline or placebo (both $\mathrm{p}<0.001$ ). Similarly, treatment with omalizumab for 16 weeks significantly reduced FceRI-positive cells in the bronchial submucosa compared with baseline or placebo (both $\mathrm{p}<0.001$ ). As mentioned previously, a close correlation has also been observed between serum IgE levels and FceRI expression on precursor dendritic cells (pDCs) from subjects with allergic asthma [18]. The effect of omalizumab on FceRI receptor expression on pDC subtypes 1 and 2 (these subtypes promote the shift of the T-cell towards the T-helper cell type 1 and 2 phenotype, respectively) has been assessed in a randomised, double-blind, placebo-controlled study in patients with seasonal allergic rhinitis [22]. Omalizumab significantly reduced FceRI expression $(p \leqslant 0.002)$ from day 7 onwards for both pDC1 and pDC2 cells, indicating that omalizumab causes a rapid decrease in FceRI $\alpha$ surface expression by dendritic cells. By downregulating FceRI

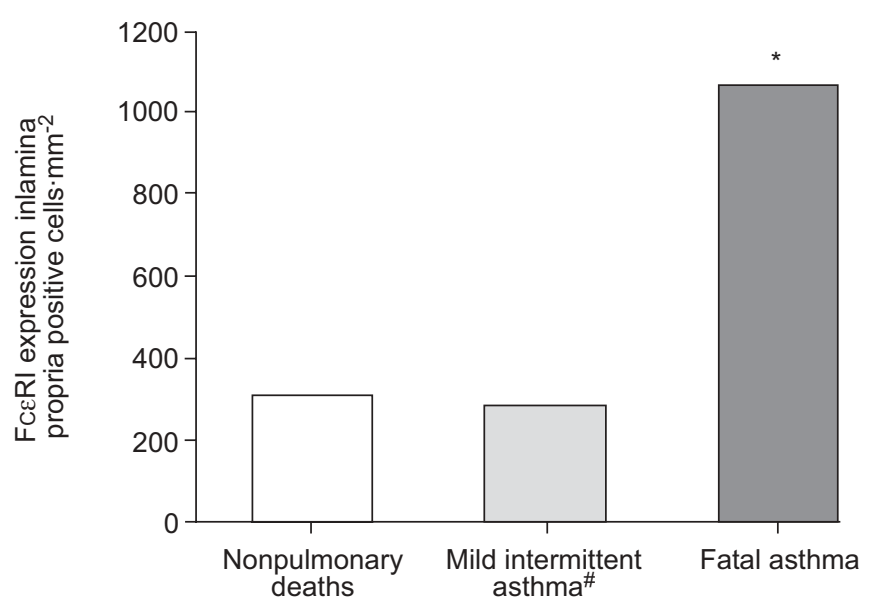

FIGURE 7. Expression of high-affinity receptors (Fc\&RI) is increased in fatal asthma [19]. $\square: n=9 ; \square: n=16 ; \square: n=10 .{ }^{*}:$ biopsy. *: $p<0.05$ versus other groups. Data taken from [19].

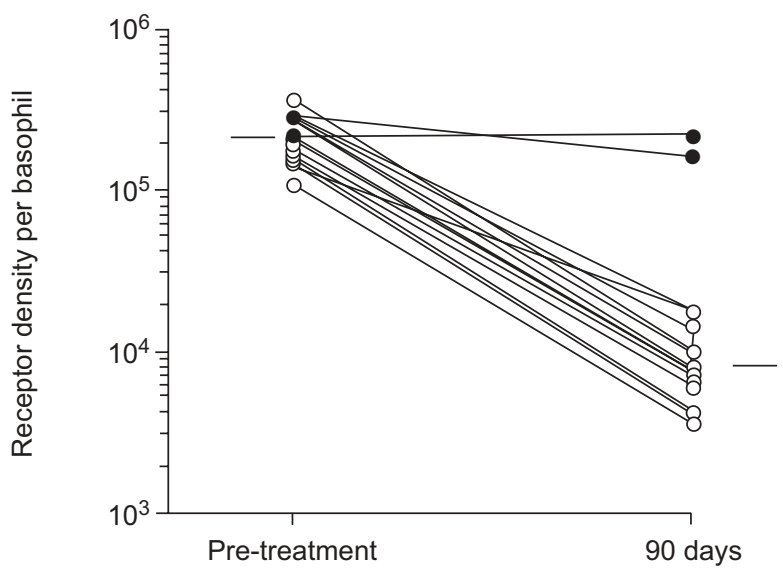

FIGURE 8. Omalizumab downregulates immunoglobulin E receptors in patients with perennial allergic rhinitis $(O ; p=0.0022)$. The horizontal lines represent the median values for omalizumab-treated patients. $\bullet$ : controls. Reproduced from [5] with permission from the publisher.

expression on dendritic cells, omalizumab may inhibit antigen processing and presentation to T-cells.

The depletion of $\operatorname{IgE}$ in airway tissue is associated with a marked reduction in airway eosinophils [21]. Omalizumab significantly reduces eosinophil numbers in airway tissue and induced sputum in patients with mild or moderate allergic asthma (fig. 9) [21]. Omalizumab treatment reduced the proportion of inflammatory cells in the sputum that were identified as eosinophils ( $4.8 \%$ at baseline, $0.6 \%$ post-treatment; $\mathrm{p}<0.001 ; \mathrm{p}=0.05$ versus placebo). The reduction in sputum eosinophil counts with omalizumab treatment was mirrored by a significant decrease in the numbers of eosinophils in both the epithelial and submucosal compartments.

The effects of omalizumab at a cellular level are reflected in clinical observations and the symptoms experienced by patients with asthma. Omalizumab inhibits the early- and late-phase asthmatic responses to inhaled allergens, as demonstrated in

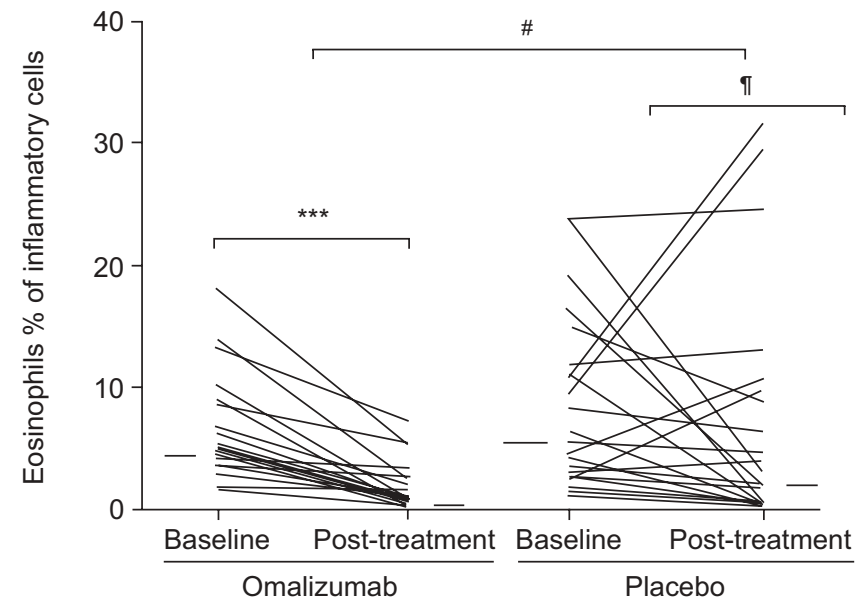

FIGURE 9. Omalizumab significantly reduces median (horizontal markers) sputum eosinophil counts. ${ }^{*}: \mathrm{p}=0.05 ;$ `: $\mathrm{p}=0.16, \mathrm{n}=22 ; * \star *: \mathrm{p}<0.001, \mathrm{n}=19$ Reproduced from [21] with permission from the publisher. 
bronchial challenge tests $[23,24]$. Assessed as the mean maximal fall in forced expiratory volume in one second, omalizumab reduced the early asthmatic response by $85 \%$ $(p=0.01)$ and the late asthmatic response by $65 \%(p=0.047)$ compared with placebo in 18 patients with mild allergic asthma [23]. Omalizumab has also been shown to decrease several markers of inflammation, including the requirement for inhaled or oral corticosteroids, in patients with moderateto-severe persistent allergic asthma [25-27]. Omalizumab significantly $(p<0.001)$ reduced the required dose of inhaled corticosteroid compared with placebo by 75 versus $50 \%$ [25] and 83 versus 50\% [26].

As omalizumab binds to the $\mathrm{C} \varepsilon 3$ site on free $\operatorname{IgE}$, the same site that binds FceRI, omalizumab cannot interact with $\operatorname{IgE}$ molecules bound to FceRI on basophils and mast cells, and does not activate effector cells by receptor cross-linking [28]. Omalizumab is, therefore, expected to be nonanaphylactogenic in clinical use.

\section{CONCLUSIONS}

The anti-inflammatory effects of omalizumab provide proof-ofconcept of the key role played by immunoglobulin $\mathrm{E}$ in allergic respiratory disease. By reducing serum immunoglobulin $\mathrm{E}$ levels and receptor expression on key cells in the inflammatory cascade, omalizumab limits the release of inflammatory mediators from mast cells and reduces the infiltration of inflammatory cells, notably eosinophils, into the airway. Omalizumab represents a novel approach to the treatment of asthma, inhibiting the inflammatory cascade before it starts.

\section{REFERENCES}

1 Holt PG, Macaubas C, Stumbles PA, Sly PD. The role of allergy in the development of asthma. Nature 1999; 402: Suppl. 6760, B12-B17.

2 Novak N, Bieber T. Allergic and nonallergic forms of atopic diseases. J Allergy Clin Immunol 2003; 112: 252-262.

3 The ENFUMOSA cross-sectional European multicentre study of the clinical phenotype of chronic severe asthma. European Network for Understanding Mechanisms of Severe Asthma. Eur Respir J 2003; 22: 470-477.

4 Global Initiative for Asthma. Global strategy for asthma management and prevention. NIH Publication No 02-3659. Bethesda, National Institutes of Health/National Heart, Lung, and Blood Institute, 2005.

5 MacGlashan DW Jr, Bochner BS, Adelman DC, et al. Downregulation of FceRI expression on human basophils during in vivo treatment of atopic patients with anti-IgE antibody. J Immunol 1997; 158: 1438-1445.

6 Illi S, von Mutius E, Lau S, et al. The pattern of atopic sensitization is associated with the development of asthma in childhood. J Allergy Clin Immunol 2001; 108: 709-714.

7 Illi S, von Mutius E, Lau S, et al. Perennial allergen sensitisation early in life and chronic asthma in children: a birth cohort study. Lancet 2006; 368: 763-770.

8 Holgate ST. Asthma and allergy - disorders of civilization? QJM 1998; 91: 171-184.

9 Louis R, Lau LC, Bron AO, Roldaan AC, Radermecker M, Djukanović $R$. The relationship between airways inflammation and asthma severity. Am J Respir Crit Care Med 2000; 161: 9-16.

10 Green RH, Brightling CE, McKenna S, et al. Asthma exacerbations and sputum eosinophil counts: a randomised controlled trial. Lancet 2002; 360: 1715-1721.

11 MacGlashan D Jr, Lichtenstein LM, McKenzie-White J, et al. Upregulation of FceRI on human basophils by IgE antibody is mediated by interaction of IgE with FceRI. J Allergy Clin Immunol 1999; 104: 492-498.

12 Williams CM, Galli SJ. The diverse potential effector and immunoregulatory roles of mast cells in allergic disease. $J$ Allergy Clin Immunol 2000; 105: 847-859.

13 Maurer D, Ebner C, Reininger B, et al. The high affinity $\operatorname{IgE}$ receptor (Fc\&RI) mediates IgE-dependent allergen presentation. J Immunol 1995; 154: 6285-6290.

14 Burrows B, Martinez FD, Halonen M, Barbee RA, Cline MG. Association of asthma with serum IgE levels and skin-test reactivity to allergens. N Engl J Med 1989; 320: 271-277.

15 Bousquet J, Rabe K, Humbert M, et al. Predicting and evaluating response to omalizumab in patients with severe allergic asthma. Respir Med 2007; 101: 1483-1492.

16 Rajakulasingam K, Durham SR, O’Brien F, et al. Enhanced expression of high-affinity $\operatorname{IgE}$ receptor (FceRI) $\alpha$ chain in human allergen-induced rhinitis with co-localization to mast cells, macrophages, eosinophils, and dendritic cells. J Allergy Clin Immunol 1997; 100: 78-86.

17 Rajakulasingam K, Till S, Ying S, et al. Increased expression of high affinity IgE (Fc\&RI) receptor- $\alpha$ chain mRNA and protein-bearing eosinophils in human allergen-induced atopic asthma. Am J Respir Crit Care Med 1998; 158: 233-240.

18 Foster B, Metcalfe DD, Prussin C. Human dendritic cell 1 and dendritic cell 2 subsets express FceRI: correlation with serum IgE and allergic asthma. J Allergy Clin Immunol 2003; 112: 1132-1138.

19 Fregonese L, Patel A, van Schadewijk A, et al. Expression of the high-affinity IgE receptor (FceRI) is increased in fatal asthma. Am J Respir Crit Care Med 2004; 169: A297.

20 Saini SS, MacGlashan DW Jr, Sterbinsky SA, et al. Downregulation of human basophil $\operatorname{IgE}$ and FceRI $\alpha$ surface densities and mediator release by anti-IgE-infusions is reversible in vitro and in vivo. I Immunol 1999; 162: 5624-5630.

21 Djukanović R, Wilson SJ, Kraft M, et al. Effects of treatment with anti-immunoglobulin $\mathrm{E}$ antibody omalizumab on airway inflammation in allergic asthma. Am J Respir Crit Care Med 2004; 170: 583-593.

22 Prussin C, Griffith DT, Boesel KM, Lin H, Foster B Casale TB. Omalizumab treatment downregulates dendritic cell FceRI expression. J Allergy Clin Immunol 2003; 112: 1147-1154.

23 Fahy JV, Fleming HE, Wong HH, et al. The effect of an antiIgE monoclonal antibody on the early- and late-phase responses to allergen inhalation in asthmatic subjects. Am J Respir Crit Care Med 1997; 155: 1828-1834.

24 Boulet LP, Chapman KR, Côté J, et al. Inhibitory effects of an anti-IgE antibody E25 on allergen-induced early asthmatic response. Am J Respir Crit Care Med 1997; 155: 1835-1840.

25 Busse W, Corren J, Lanier BQ, et al. Omalizumab, anti-IgE recombinant humanized monoclonal antibody, for the 
treatment of severe allergic asthma. J Allergy Clin Immunol 2001; 108: 184-190.

26 Solèr M, Matz J, Townley R, et al. The anti-IgE antibody omalizumab reduces exacerbations and steroid requirement in allergic asthmatics. Eur Respir J 2001; 18: 254-261.
27 Milgrom H, Fick RB Jr, Su JQ, et al. Treatment of allergic asthma with monoclonal anti-IgE antibody. rhuMAb-E25 Study Group. N Engl J Med 1999; 341: 1966-1973.

28 Presta LG, Lahr SJ, Shields RL, et al. Humanization of an antibody directed against IgE. J Immunol 1993; 151: 2623-2632. 